\title{
Exploring the myrmecofauna of Sicily: thirty-two new ant species recorded, including six new to Italy and many new aliens (Hymenoptera, Formicidae)
}

\author{
ENRICO SCHIFANI $^{1 *}$, ANTONIO ALICATA $^{2}$ \\ ${ }^{1}$ Section Animal Biology, Department STEBICEF, University of Palermo - Via Archirafi \\ 18, I-90123, Palermo, Italy; ORCID iD: https://orcid.org/0000-0003-0684-6229 \\ ${ }^{2}$ Via Passo Gravina 245/12, I-95125, Catania, Italy
}

\begin{abstract}
As a result of recent collecting efforts and older unpublished data of one of us (AA), 32 ant species (including 2 morphospecies) new to the island of Sicily (Italy) were discovered. Seven of these taxa represent unequivocally exotic entities, whose discovery marks a decisive increase of this component in the local fauna. Among these, two forms of Nylanderia EMERY, 1906 are treated as morphospecies because of the problematic taxonomy of the genus. Six taxa among the discovered species are entirely new to the myrmecofauna of Italy. Finally, Tetramorium indocile SANTSCHI, 1927 is reported for the first time as a host for the social parasite Strongylognathus testaceus (SCHENCK, 1852). The state of the art of the Sicilian myrmecofauna, now counting about 150 species, is commented on.
\end{abstract}

KEY WORDS: Species distribution, introduced species, invasive ants, rare species, social parasites, faunistics, new records.

\section{INTRODUCTION}

Sicily is the largest island in the Mediterranean Sea $\left(25711 \mathrm{~km}^{2}\right)$. Located between the Italian peninsula and Africa, it is about 145 kilometres distant from Tunisia and $3 \mathrm{~km}$ from peninsular Italy, and placed in the easternmost part of the Western Mediterranean area

\footnotetext{
* Corresponding author: enrsc8@gmail.com
} 
(VIGNA TAGLIANTI et al. 1993); it is therefore characterized by a particular biogeographical condition (LA GRECA 1957, MASSA et al. 2011).

Scientific knowledge of the Sicilian myrmecofauna has its origins in the first half of the $19^{\text {th }}$ century and its early history was summarized by BARONI URBANI (1964). A number of more recent sources provide checklists of the ants of Sicily, but none of them strictly focuses on this topic. The term Sicily has been used ambiguously several times by these sources: in some cases they refer only to the main island, while in others they include all or at least part of the circumsicilian islands (Egadi Islands, Aeolian Is., Pantelleria, Pelagie Islands. and Ustica) without being specific. The circumsicilian islands are geologically and biologically heterogeneous (MusCARELLA \& BARAGONA 2017). The Pelagie Islands and Pantelleria differ the most from Sicily in terms of their ant fauna (see MEI 1995). The work of BARONI URBANI (1971) represents the most complete existing source in which the aforementioned distinction is clearly made, but it is obviously outdated. Fauna Italia (POLDI et al. 1995), Fauna Europaea (MITROIU et al. 2015), BorowIEC (2014) and Antmaps (JANICKI et al. 2016) do not make this distinction (or make only a partial distinction as in the case of Antmaps), sometimes creating confusion: for example, Antmaps incorrectly lists Leptanilla poggii MeI, 1995 for both Pantelleria and Sicily, whereas in fact it has so far been recorded from only the former. However, these lists are based on records that have already been published elsewhere, whose precise geographical attribution is usually verifiable in the original source. An exception to this is the first record of Lasius fuliginosus (LATREILLE, 1798) published by POLDI et al. (1995), which is clarified in the present study. Moreover, ten records originally published by Fauna Europaea (and then also reported by BOROWIEC \& SALATA (2012), BOROWIEC (2014), WETTERER (2010b) and Antmaps) were new when published. These records may simply represent mistakes, as they include many unexplained and particularly aberrant data (e.g. Camponotus samius Forel, 1889 in Sicily; Messor caducus (MOTSCHULSKY, 1839) in Sicily, Sardinia and peninsular Italy) and because in general one does not expect to find new records in Fauna Europaea. Currently, Antmaps provides the most complete list of ant records for Sicily, which also covers all the circumsicilian islands except Pantelleria and the Pelagie Islands. However, Temnothorax flavicornis (EMERY, 1870) and T. unifasciatus (LATREILLE, 1798), which were recorded by BUSCHINGER et al. (1988), are not listed by Antmaps. Moreover, Antmaps incorrectly lists Temnothorax kraussei (no name of the describing author of the taxon or date of the original description is given): in fact, the source cited by Antmaps (GALKOWSKI \& CAGNIANT 2017) does not contain such a record. Following the most recent nomenclature (WARD et al. 2015), T. mediterraneus WARD, BRADY, FISCHER \& SCHULTZ, 2015 (which is also present in the Antmaps list) is the correct name for T. kraussei EMERY, 1916 (and Sicily is among the localities stated by EMERY (1916)). On the other hand, T. kraussei (EMERY, 1915), formerly known as Epimyrma kraussei EMERY, 1915, has never been recorded in Sicily. 
In conclusion, the total number of valid ant taxa recorded unambiguously for Sicily currently stands at about 120 . Still, confirmation is required for many species historically recorded in Sicily as relevant taxonomic advances have changed the boundaries of those species.

\section{MATERIAL AND METHODS}

The records presented here are all either based on material that has been directly investigated by us (stored in the authors' personal collections), or unpublished data obtained from other myrmecologists (other collections).

They are all from Sicily, excluding the circumsicilian islands (Fig. 1). To prevent any confusion, we will only use the term Sicily sensu stricto.

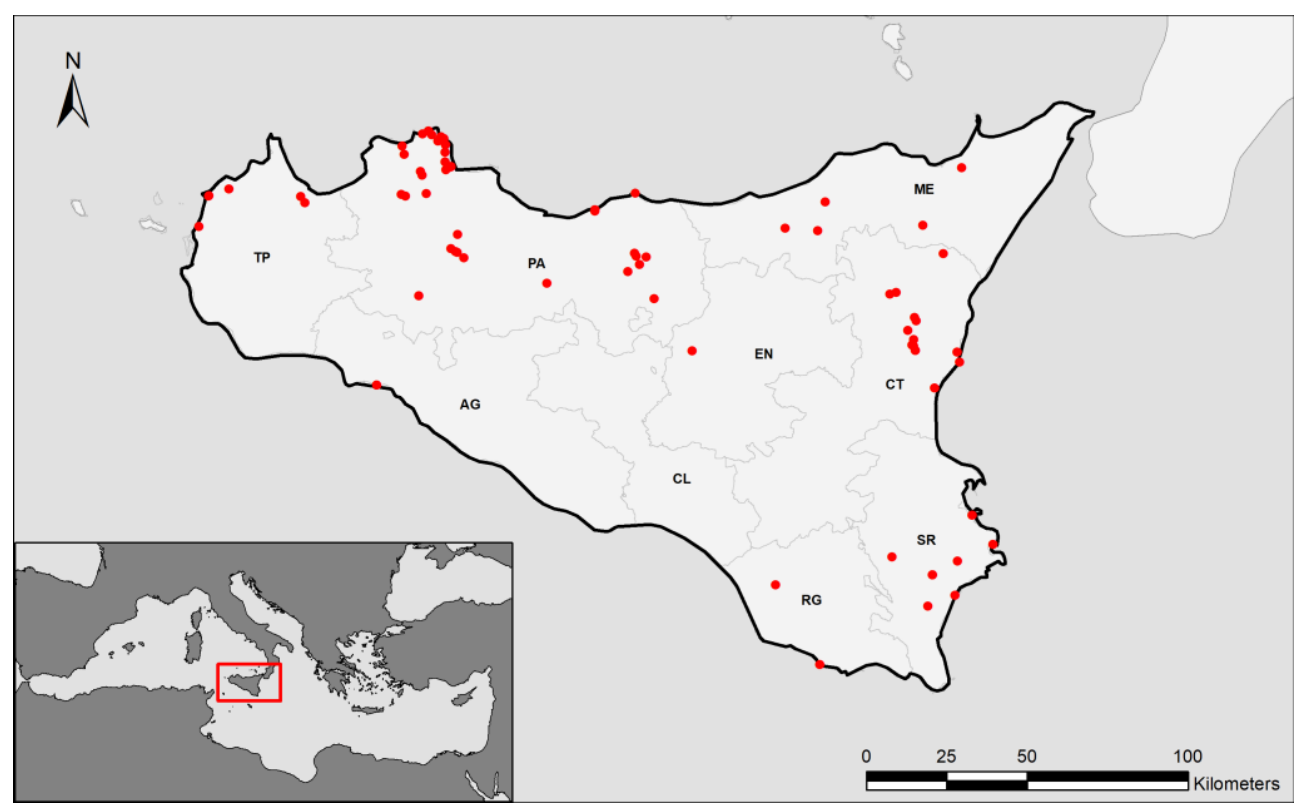

Fig. 1. Map of the island of Sicily in the Mediterranean Sea. The red dots represent points where ant species new to the island's fauna were collected.

Most of the ants were collected by direct sampling; other, different techniques are explicitly mentioned whenever they were used. 
The cryptic species of the caespitum-complex were identified with the online key provided by WAGNER et al. (2017) at https://webapp.uibk.ac.at/ecology/tetramorium/.

Images of specimens were taken using a Canon 1300D reflex and MP-E $65 \mathrm{~mm} \mathrm{f} / 2.8$ 1-5x Macro Photo lens. Helicon Focus 6.7.1, method C, was used to fuse images taken in different focal planes into single images with greater depth of field. When necessary, absolute measurements were taken using the ImageJ program.

Antmaps was used to give a general idea of the global distribution of each species, and more specific comments are given for distributions in regions which are biogeographically relevant to their presence in Sicily.

List of abbreviations: AACI - Antonio ALICATA personal collection, Catania, Italy; CGSF - Cristophe GALKOWSKI personal collection, Saint-Aubin-de-Medoc, France; CLCF - Claude LEBAS personal collection, Canohès, France; DBET - Department of Biodiversity and Evolutionary Taxonomy, University of Wroclaw, Wroclaw, Poland; EEPI - Enrico SCHIFANI personal collection, Palermo, Italy; MCSNM - Museo Civico di Storia Naturale di Milano, Milano, Italy; RBMF - Rumsaïs BLATRIX personal collection, Montpellier, France.

\section{LIST OF SPECIES NEW TO THE SICILIAN ANT FAUNA}

\section{Aphaenogaster italica BONDROIT, 1918}

New data: Pizzo della Battaglia, Nebrodi (ME), 1,000 m, glade in Quercus cerris L. woods, 17 Jun 1993, A. ALICATA lgt, AACI and MCSNM. Bosco Scavioli, Nebrodi (ME), Alcara Li Fusi, 1,400 m, glade in Fagus sylvatica L. woods, 7 Oct 2001 G. SorgI lgt. AACI.

Global distribution: A rarely collected species, known from only a few localities in Italy (including Calabria) (BARONI URBANI 1971) and Switzerland (KUTTER 1977). Antmaps gives an additional record from the Aegean Islands but this is based on a clear misinterpretation of the cited source (FINZI 1930).

Notes: The Sicilian record represents the new southernmost known point in the distribution of this species.

2. Aphaenogaster subterranea $\mathrm{ssp}$. ichnusa SANTSCHI, 1925

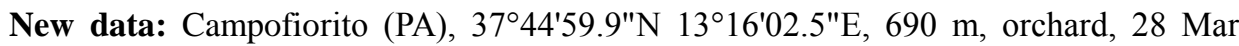

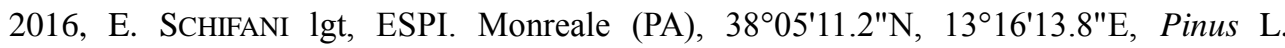
reforestation, 590 m, 8 May 2016, E. SCHIFANI lgt, ESPI. Cava Grande (SR), 36 $58^{\prime} 45.6^{\prime \prime N}$, $15^{\circ} 04^{\prime} 41.9^{\prime \prime E}$, Quercus ilex L. woods, 340 m, 3 Sept 2016, E. SCHIFANI lgt, ESPI. Bosco del Cappelliere (PA), 37 $55^{\prime} 40.4^{\prime \prime} \mathrm{N} 13^{\circ} 23^{\prime} 05.3^{\prime \prime} \mathrm{E}, 510 \mathrm{~m}$, deciduous woods of the $Q$. 
pubescens WILLD. group, 24 Sept 2016, E. SCHIFANI lgt, ESPI. Malasà (ME), 3805'25.6" N, 15¹3'29.2"E, 560 m, mixed woods, 16 Nov 2016, E. SCHIFANI lgt, ESPI. Parco della Favorita, Palermo, 3809'41.5"N, 13²0'18.1"E, 50 m, Quercus ilex woods, 02 Feb 2017, E. SCHIFANI lgt, ESPI. M. Moarda, Altofonte (PA), 38 $02^{\prime} 11.4^{\prime \prime N}, 13^{\circ} 17^{\prime} 17.9^{\prime \prime} \mathrm{E}, 590 \mathrm{~m}$, Pinus reforestation, 11 May 2017, E. SCHIFANI lgt, ESPI. Etna (CT), 37³9'53.4"N, 1459'31.2"E, 1,230 m, chestnut woods, 14 May 2017, E. SCHIFANI lgt, ESPI. Bosco di Aglisotto (PA), $38^{\circ} 01^{\prime} 35.3^{\prime \prime N}, 13^{\circ} 11^{\prime} 57.0^{\prime \prime E}, 950 \mathrm{~m}$, Pinus reforestation, 26 May 2017, E. Schifani lgt, ESPI. C. da Cuca, Polizzi Generosa (PA), 37 $49^{\prime} 27.8^{\prime \prime} \mathrm{N}, 14^{\circ} 00^{\prime} 11.3^{\prime \prime} \mathrm{E}, 740 \mathrm{~m}$, orchard, Sept 2017, E. Genduso lgt, ESPI. M. Petroso (PA), 3805'50.9"N, 13¹5'54.3"E, 510 m, Quercus ilex woods, 2 Sept 2017 E. SCHIFANI lgt, ESPI. Galati Mamertino (ME), $38^{\circ} 01^{\prime} 32.9^{\prime \prime N}, 14^{\circ} 46^{\prime} 32.4^{\prime \prime E}, 920$ m, Pinus reforestation, 14 Jul 2017, L. BERTONI lgt, ESPI.

Global distribution: Sardinia (see below).

Notes: This subspecific form, previously known only as a Sardinian endemic, represents a more thermophilic entity related to the true A. subterranea (LATREILLE, 1798) and it is currently under taxonomic revision (R. BLATRIX pers. comm.). A. subterranea $\mathrm{s}$. str. was found at higher altitudes in Sicily, in glades in Fagus sylvatica woods between 1,200 and 1,500 $\mathrm{m}$ in the Madonie (PA) and Nebrodi (ME) mountains and probably reaches even higher altitudes. The distribution of these entities in the Italian peninsula has yet to be studied. However, preliminary data suggest a strong latitudinal gradient in their altitudinal preferences: low altitude samples from Southern Italy (Aspromonte, Bova, 3758'58.5"N $15^{\circ} 56^{\prime} 30.5^{\prime \prime E}, 500 \mathrm{~m}, 13$ Nov 2016, E. SCHIFANI lgt, ESPI) and Central Italy (Villa Borghese, Rome, 41 ${ }^{\circ} 55^{\prime} 37.7^{\prime \prime N}, 12^{\circ} 30^{\prime} 02.2^{\prime \prime E}, 13$ Sept 2017, E. SCHIFANI lgt, ESPI) also appear to belong to A. subterranea ichnusa (ESPI), whereas only A. subterranea s. str. was found in Northern Italy (Pontescodogna, Parma, 44⒋'18.6"N, 10¹1'43.4"E, 120 m, 02 Aug 2018, E. SCHIFANI lgt, ESPI - winged sexuals inside the nest). In Sicily, four dealate queens of A. subterranea ichnusa were found in a large nest near Monreale (PA), while winged sexuals were found inside a nest during September in M. Petroso (PA).

\section{Bothriomyrmex corsicus SANTSCHI, 1923}

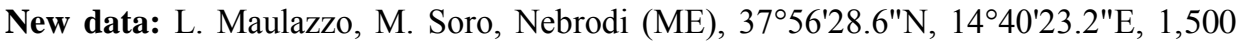
$\mathrm{m}$, meadow near the lake, 1 Aug 2014, E. SCHIFANI lgt, ESPI. Laghetti coda di riccio, Bosco della Ficuzza (PA), 37052'26.7"N, 132 $23^{\prime} 59.6^{\prime \prime} \mathrm{E}, 860 \mathrm{~m}$, meadow near the ponds, 11

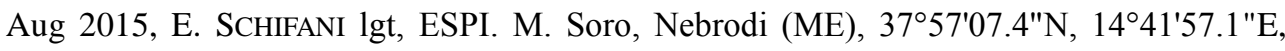
1,350 m, meadow near a pond, 7 Aug 2016, E. SCHIFANI lgt, ESPI. L. Maulazzo, M. Soro, Nebrodi (ME), 3756'27.1"N, 14²40'12.8"E, 1,500 m, 22 Apr 2018, R. BLATRIX lgt, RBMF. Piano della Battaglietta, M. Carbonara, Madonie (PA), 3752'49"N, 1401'59"E, 1,610 m, meadow, 07 Jul 2018, R. VIVIANO lgt, ESPI.

Global distribution: From Europe to the Caucasus. 
Notes: Bothriomyrmex EMERY, 1869 has been known in Sicily since an old record of $B$. meridionalis (ROGER, 1863) by EMERY (1915). The following lists refer only to the endemic B. adriacus ionius var. sicula (EMERY, 1925) (EMERY 1925, DONISTHORPE 1927, BARONI URBANI 1971, as B. sicula by POLDI et al. 1995) that was later declared an unavailable infrasubspecific name (SHATTUCK 1994). The current understanding of the genus in Europe is based on the revision by SEIFERT (2012a), which synonymized $B$. meridionalis var. adriaca SANTSCHI, 1922 with B. communista SANTSCHI, 1919 and clarified the identity of the Western Palaearctic species. B. communista in Sicily occurs in relatively thermophilous sites (Taormina in DONISTHORPE 1927, CASENT0906241;

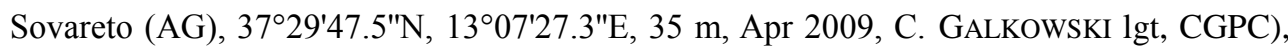
while B. corsicus seems to occur at higher altitudes (as expected, see SEIFERT 2012a).

\section{Camponotus tergestinus MÜLLER, 1921}

New data: Buonriposo (EN), 37³6'20.0"N, 14²14'41.4"E, $700 \mathrm{~m}$, Quercus gr. pubescens forest, pitfall trap, 6 Nov 2007, A. ALICATA lgt., AACI.

Global distribution: From Balkans to the Italian peninsula (including Calabria) (BRAČKO 2017).

Notes: C. tergestinus is a rarely collected species, whose nests are probably restricted to oak forest canopies (BRAČKO 2017). This is the new southernmost known point of distribution for this species.

\section{Cardiocondyla mauritanica FOREL, 1890}

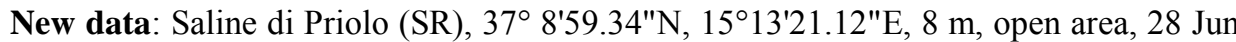



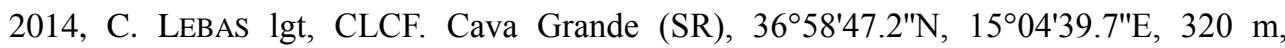
carbonate rocks near the water, 4 Sept 2016, E. SCHIFANI lgt, ESPI. Avola (SR), $36^{\circ} 55^{\prime} 22.2^{\prime \prime} \mathrm{N}, 15^{\circ} 09^{\prime} 21.9^{\prime \prime} \mathrm{E}, 18 \mathrm{~m}$, sidewalk, 4 Sept 2016, E. SCHIFANI lgt, ESPI. Protonotaro (ME), 38 $07^{\prime} 12.4^{\prime \prime N}, 15^{\circ} 10^{\prime} 57.2^{\prime \prime} \mathrm{E}, 75 \mathrm{~m}$, citrus orchard, 16 Oct 2016, E. SCHIFANI lgt, ESPI. Cefalù (PA), 1 Jul 2017, R. BLATRIX lgt, RBMF.

Global distribution: Worldwide, probably a native of subtropical areas from North Africa to South Asia (WETTERER 2012). It appears to be rapidly expanding its range along the Western Mediterranean coast and in the Balearic Islands (GÓMEZ \& ESPADALER 2006). Its presence was known from the nearby areas of Gozo, Malta (SEIFERT et al. 2017) and Pantelleria (MEI 1995, SCUPOLA 2009).

Notes: The boundaries of the native distribution of this species are still not well understood. Since North Africa has been generally considered part of its native range (WETTERER 2012, SEIFERT et al. 2017), the nature of its presence in Sicily appears difficult to determine, also considering the heterogeneous set of habitats (both anthropogenic and 
natural) in which it was collected. In Avola, the site where $C$. mauritanica occurred, was also invaded by the Argentine ant, Linepithema humile (MAYR, 1868). Such a peculiar case of coexistence has also been noted elsewhere (WARD 2005, GÓMEZ \& ESPADALER 2006).

6. Cataglyphis viatica (FABRICIUS, 1787)

New data: Poggio Gerbe, Vittoria (RG), on a trail, 30 Mar 2001, A. Alicata lgt, AACI.

Global distribution: A species recorded from Iberia, Northern Africa and the Horn of Africa.

Notes: $C$. viatica represents the second species of the genus in Italy, after the endemic C. italica (EMERY, 1906) which is absent from Sicily. An old record by COLLINGWOOD (1963) of C. cursor (FONSCOLOMBE, 1846) in Sicily (without any precise locality) was never confirmed by subsequent findings and has been excluded from more recent lists (PoLDI et al. 1995, Antmaps). While CoLLINGWOOD (1963) was unlikely to have referred to the true $C$. cursor (BARONI URBANI 1971), his record appears even less likely to refer to $C$. viatica, which belongs to a distinctly different species group.

7. Dolichoderus quadripunctatus (LiNNAEUS, 1771)

New data: Bosco di Baulì, Palazzolo Acreide (SR), pitfall traps, 28 Jul 2001, A.

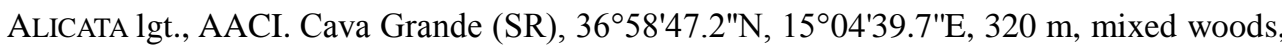
4 Sept 2016, E. SCHIFANI lgt, ESPI.

Global distribution: From Europe to Central Asia.

Notes: This record represents the new southernmost known point of distribution in Europe for this species. A previous record from Sicily sensu lato, originally published by Fauna Europaea, is difficult to interpret and according to Antmaps needs verification. In the Cava Grande canyon workers were found foraging in shady areas on both trees (associated with aphids) and on the rocks near the water.

\section{Lasius (Chthonolasius) bicornis (FOERSTER, 1850)}

New data: Bosco di Malabotta, Montalbano Elicona (ME), on a trail in Fagus sylvatica woods, 6 Jun 1993, A. AliCATA lgt, AACI.

Global distribution: A Palaearctic species ranging from Europe to Eastern Russia and also present in the Maghreb.

Notes: $L$. bicornis, a temporary social parasite, is a rarely collected species whose host is likely to be L. brunneus (LATREILLE, 1798) (VANKERKHOVEN et al. 2018). It was already known from the Italian peninsula and Sardinia (POLDI et al. 1995). 
9. Lasius (Chthonolasius) umbratus (NYLANDER, 1846)

New data: Etna (CT), M. Scavo, 1,785 m, Pinus woods, 24 Jul 1992, A. AliCaTA lgt, AACI. Etna (CT), Grotta delle Palombe, 1,500 m, mixed woods, 10 Oct 1992, A. AliCATA lgt, AACI. Etna (CT), M. Rosso, 1,755 m, Pinus woods, 10 Oct 1992, A. Alicata lgt, AACI.

Global distribution: Palaearctic. Until recently, this taxon was considered to be one of the few Holarctic ant species (SCHÄR et al. 2018).

Notes: $L$. umbratus is a temporary social parasite at the expense of several Lasius s. str. species (SEIFERT 2007). It was already known in the Italian peninsula and in Sardinia (POLDI et al. 1995).

10. Lasius (Dendrolasius) fuliginosus (LATREILLE, 1798)

New data: Etna (CT), M. Egitto, 23 Jul 1992, nest at the basis of a Pinus tree, A. ALICATA lgt, AACI and MCSNM.

Global distribution: From Europe to Central Asia.

Notes: Well known in the Italian peninsula, L. fuliginosus was also recorded for Sicily sensu lato by POLDI et al. (1995), probably on the basis of this same material (Fabrizio RIGATO pers. comm.). This species exhibits social hyperparasitism as it is a temporary social parasite whose hosts are represented by several congeneric species of the subgenus Chthonolasius RUZSKY, 1912. Both L. bicornis and L. umbratus, the only two Chthonolasius known in Sicily, are possible host species for L. fuliginosus according to SEIFERT (2007). This is the new southernmost known point of distribution of L. fuliginosus. As Mt. Etna is currently the sole known locality of this species in Sicily, it is possible to speculate that it may have been accidentally introduced through reforestation projects.

11. Lasius (Lasius) lasioides (EMERY, 1869)

New data: Sovareto (AG), $37^{\circ} 29^{\prime} 47.5^{\prime \prime} \mathrm{N}, 1^{\circ} 07^{\prime} 27.3^{\prime \prime E}, 35 \mathrm{~m}$, Apr 2009, C. GALKOWSKI lgt, CGSF. Niscemi (CL), Jun 2010, S. TOMARCHIO lgt, ESPI. Campofelice di

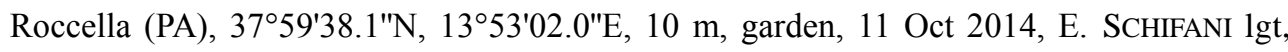
ESPI. Palermo, Mondello, 9 Feb 2016, 38 $8^{\circ} 11^{\prime} 43 \mathrm{~N}, 13^{\circ} 20^{\prime} 07.7^{\prime \prime E}, 5 \mathrm{~m}$, garden, E. SCHIFANI lgt, ESPI. Campofiorito (PA), 37 $44^{\prime} 57.2^{\prime \prime N}, 13^{\circ} 16^{\prime} 02.4^{\prime \prime E}, 675 \mathrm{~m}$, olive orchard, $28 \mathrm{Mar}$

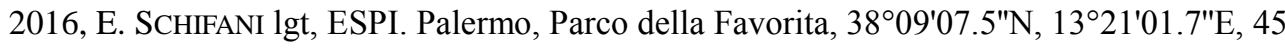
m, dense Mediterranean maquis 1 Mar 2016, E. SCHIFANI lgt, ESPI. Palermo, Orto Botanico dell'Università di Palermo, $38^{\circ} 06^{\prime} 43.6^{\prime \prime} \mathrm{N}, 13^{\circ} 22^{\prime} 21.5^{\prime \prime} \mathrm{E}, 10 \mathrm{~m}$, garden, 7 Apr

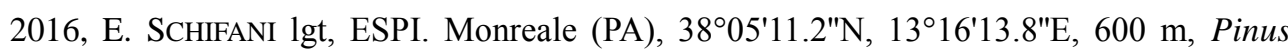
reforestation, 8 Apr 2016, E. SCHIFANI lgt, ESPI. Bosco Scalia (PA), 38 01'39.9"N, 1312'46"E, $815 \mathrm{~m}$, Quercus ilex forest edge, 9 Apr 2016, E. SChIFANI lgt, ESPI. M. Pellegrino (PA), 38 $10^{\circ} 23.4^{\prime \prime} \mathrm{N}, 13^{\circ} 21^{\prime} 04.5^{\prime \prime} \mathrm{E}, 395$ m, Pinus reforestation, 12 Apr 2016, E. 
SCHIFANI lgt, ESPI. Alia (PA), 3704'21.1"N, 13ํ3'06.5"E, 660 m, 21 Apr 2016, garden, E.

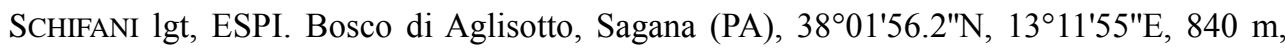
Pinus reforestation, 7 May 2016, E. SCHIFANI lgt, ESPI. Capo Gallo (PA), 38 $12^{\prime} 40^{\prime \prime}$, $13^{\circ} 17^{\prime} 25^{\prime \prime}$ E, 50 m, Pinus reforestation, 24 May 2016, E. SCHIFANI lgt, ESPI. Altofonte (PA), M. Moarda, 38 $02^{\prime} 07.4^{\prime \prime N}, 13^{\circ} 17^{\prime} 15.3^{\prime \prime E}, 630 \mathrm{~m}$, Pinus reforestation, 30 May 2016, E. SCHIFANI lgt, ESPI. Palermo, Sferracavallo, 38 $12^{\circ} 07.8^{\prime \prime N}, 13^{\circ} 16^{\prime} 11.4^{\prime \prime} \mathrm{E}, 5 \mathrm{~m}$, garden, 12

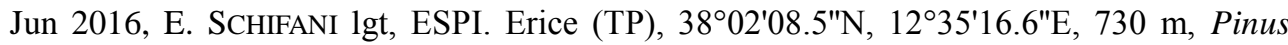
reforestation, 11 Nov 2016, E. SCHIFANI lgt, ESPI. M. Gallo (PA), Pinus reforestation, 10

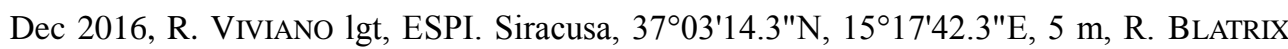

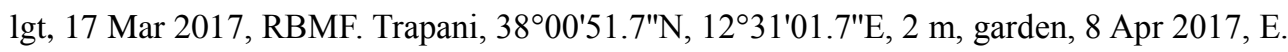
SCHIFANI lgt, ESPI. M. Petroso (PA), 38 $08^{\circ} 50.9^{\prime \prime} \mathrm{N}, 13^{\circ} 15^{\prime} 54.3^{\prime \prime} \mathrm{E}, 520 \mathrm{~m}$, Quercus ilex

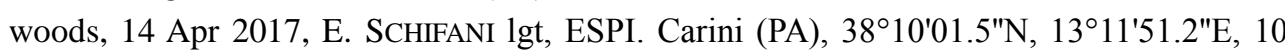
m, garden, 17 Apr 2017, R. VIVIANO lgt, ESPI. Nicolosi (CT), 37³6'28.7"N, 1501'04.2"E, 740 m, Mediterranean maquis, 14 May 2017, E. SCHIFANI lgt, ESPI. Alcamo Marina (TP), Jul 2017, G. HEBDA lgt, DBET. Castellammare del Golfo (TP), 3801'11.4"N, 1250'33.9"E, 220 m, garden, 3 Sept 2017, E. SchIFANi lgt, ESPI. Ragalna (CT), C.da Milia, Oct 2017, S. TOMARCHIO lgt, ESPI.

Global distribution: Mediterranean region and Central Asia.

Notes: L. lasioides was already known in peninsular Italy (SEIFERT 1992), Malta (SCHEMBRI \& COLLINGWOOD 1995), Pantelleria (MEI 1995) and Sardinia (RIGATO \& TONI 2011). Although not previously recorded in Sicily, this species is very common, often being the only Lasius species found from low to medium altitudes, where it is found in almost any habitat with some arboreal vegetation. Nests are found under rocks or in rotten wood, and workers are often observed foraging on trees and bushes. Reproductive flights were observed between June and July in Mondello.

Before SEIFERT's (1992) taxonomic revision the whole Lasius s. str. group was quite poorly understood, and L. lasioides was considered a junior synonym of $L$. alienus (FOERSTER, 1850) since WILSON (1955), which largely explains the absence of Sicilian records for this species (also noted for Malta by SCHEMBRI \& COLLINGWOOD 1995). In addition, there is a doubtful record by DONISTHORPE (1927) of Acanthomyops (Donisthorpea) brunneus var. nigro-brunnea, which according to him differed from the true A. (Donisthorpea) brunneus (=L. brunneus) in its preference for nesting under rocks (not only in the wood) and by its darker colour. Even if DONISTHORPE's record of the var. nigrobrunnea was later interpreted as L. brunneus by BARONI URBANI (1971), it could be referred to L. lasioides, which shares some morphological traits with L. brunneus but fits the differential description proposed by DONISTHORPE. Confusion between L. brunneus and L. lasioides in the past has also been reported for Greece by BOROWIEC \& SALATA (2012). 
In conclusion, no Lasius s. str. record for Sicily before 1992 should be considered valid without verification.

12. Lasius (Lasius) cf. paralienus SEIFERT, 1992

New data: Godrano (PA), Gorgo del Drago, 3754'03.8"N, 1324'44.4"E, 860 m, mixed woods, 30 Apr 2016, E. SCHIFANI lgt, ESPI. Bosco del Cappelliere (PA), 3755'26.8"N, 132'49.8"E, 580 m, oak woods, 24 Sept 2016, E. SchIFANI lgt, ESPI. Ficuzza (PA),

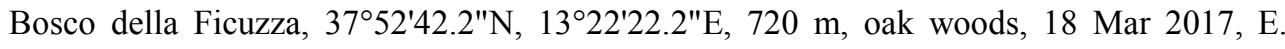
SCHIFANI lgt, ESPI. Altofonte (PA), M. Moarda, 38 $01^{\circ} 58.6^{\prime \prime N}, 13^{\circ} 17^{\prime} 32.0^{\prime \prime} \mathrm{E}, 850 \mathrm{~m}$, mixed

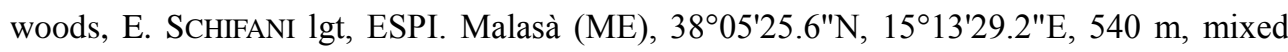
woods, 15 Oct 2017, E. SCHIFANI lgt, ESPI. Nicolosi (CT), M.ti Rossi, 37³8'21.6"N, $15^{\circ} 00^{\prime} 43^{\prime \prime E}, 920$ m, Pinus reforestation, 14 May 2017, E. SCHIFANI lgt, ESPI. Etna (CT),

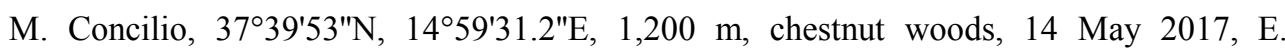
SCHIFANI lgt, ESPI. Erice (TP), 38 $02^{\circ} 23.8^{\prime \prime} \mathrm{N}, 12^{\circ} 35^{\prime} 09.3^{\prime \prime E}, 710 \mathrm{~m}$, mixed woods, 4 Nov 2017, E. SCHIFANI lgt. ESPI. Polizzi Generosa, Madonie (PA), 37²49'27.8"N, 1400'10.1"E, 740 m, orchard, 15 Sept 2018, E. SCHIFANI lgt, ESPI.

Global distribution: Europe and east to Iran.

Notes: These specimens represent a form clearly belonging to the $L$. paralienus complex, whose conspecificity with the true $L$. paralienus requires further investigation. $L$. cf. paralienus is found at mid altitudes within the forested areas of Sicily, usually where broadleaved trees (e.g. oaks) are also present. Confusion with $L$. alienus (and possibly even L. niger) may have occurred in the past prior to SEIFERT's (1992) taxonomic revision.

\section{Lasius (Lasius) psammophilus SEIFERT, 1992}

New data: Etna (CT), $37^{\circ} 42^{\prime} 05.1^{\prime \prime N}, 15^{\circ} 00^{\prime} 55^{\prime \prime} \mathrm{E}, 1,840 \mathrm{~m}$, Pinus on lava sands, Sept 2014, C. LeBAS lgt, CLCF. Mufara (PA), Madonie, 1,835 m, meadow near Fagus sylvatica forest, Jun 2016, E. Schifani lgt, ESPI. Laghetto Monte Soro, M. Soro, Nebrodi (ME), $37^{\circ} 57^{\prime} 01.5^{\prime \prime N}, 14^{\circ} 41^{\prime} 07.4^{\prime \prime E}, 1,400$ m, meadow near Fagus sylvatica forest, 7 Aug 2016, E. SCHIFANI lgt, ESPI. M. Carbonara, Madonie (PA), 3752'53.4"N 1401'06.6"E, 1,710 m, 24 Apr 2018, R. BlatRIX lgt, ESPI and RBMF. Mandria del Conte, Madonie (PA), $37^{\circ} 52^{\prime} 48^{\prime \prime N}, 14^{\circ} 00^{\prime} 11 " \mathrm{E}, 1,255 \mathrm{~m}, 7 \mathrm{Jul}$ 2018, R. Viviano lgt, ESPI.

Global distribution: Europe, Western Russia and Turkey.

Notes: L. psammophilus in Italy was only known to occur in the northern parts of the Italian peninsula (GLASER et al. 2012, Antmaps). Confusion with L. alienus may have occurred before SEIFERT's revision (1992) as in L. lasioides. However, L. psammophilus is obviously far less common than L. lasioides in Sicily. 
14. Leptanilla poggii MEI, 1995

New data: Cava S. Chiara, Noto (SR), soil under Opuntia, 21 Apr 2001, G. SABELLA lgt., AACI.

Global distribution: Until now, this species was only known from Pantelleria (MEI 1995).

Notes: The genus Leptanilla EMERY, 1870 suffers from a very fragmentary taxonomy owing to the scarcity of collected material and difficulties in the morphological study of these minute ants. In addition, many Mediterranean species are only known from either male or female castes because of the difficulty of collecting them together (SCUPOLA \& BALLARIN 2009). In Sicily, at least two species were known to be present. These were only known from male specimens, which did not match any known male of the genus and were thus provisionally named as Leptanilla sp. SIC-1 and Leptanilla sp. SIC-2 (SCUPOLA \& BALLARIN 2009). A molecular comparison will be needed to establish if one of those morphospecies coincides with L. poggii.

\section{Messor ibericus SANTSCHI, 1931}

New data: M. Columbrina (PA), Feb 2016, meadow, E. SCHIFANI lgt., ESPI. Altofonte (PA), M. Moarda, 38 $02^{\prime} 12.1^{\prime \prime N}, 13^{\circ} 17^{\prime} 22.5^{\prime \prime E}, 550 \mathrm{~m}$, trail across Pinus reforestation, 30 May 2016, E. SCHIFANI lgt., ESPI. Polizzi Generosa (PA), 3749'28.6"N 1400'10.6"E, 730 m, meadow, Aug 2016, E. GENDUSo lgt., ESPI. Cava Grande (SR), 3658'47.2"N, 1504'39.7"E, 320 m, meadow, 3 Sept 2016, E. SCHIFANI lgt., ESPI. Bompietro (PA), Oct 2016, 37 $45^{\prime} 01.9^{\prime \prime N}, 1^{\circ} 05^{\prime} 49.7^{\prime \prime E}, 740$ m, meadow, E. SCHIFANi lgt., ESPI. Sagana (PA), 17 Apr 2017, meadow, E. SCHIFANI lgt., ESPI. Nicolosi (CT), 37³6'31.1"N, 1501'08.0"E, 700 m, meadow, 14 May 2017, E. SchIFANI lgt., ESPI. Ficuzza (PA), 3752'55.5"N, $13^{\circ} 22^{\prime} 37.2^{\prime \prime E}, 680$ m, meadow, 15 Jun 2016, E. SCHIFANI lgt., ESPI. M. Pellegrino (PA), 38¹1'22.3"N, 13²0'08.9"E, 65 m, meadow, 18 Nov 2017, E. SCHIFANI lgt., ESPI. Gorgo


2018, E. SCHIFANI lgt., ESPI.

Global distribution: South-European, the only subcryptic species of the M. structor (LATREILLE, 1798) group certainly present in Italy (STEINER et al. 2018).

Notes: M. structor was recorded multiple times in the past from Sicily, but has undergone a long 'taxonomic odyssey' which only recently ended (STEINER et al. 2018). However, no Sicilian material was examined by STEINER et al. (2018). All the Sicilian specimens we had previously identified as $M$. structor now belong to $M$. ibericus according to STEINER et al. (2018), and the true M. structor is probably absent from Sicily. 
16. Myrmica lobulicornis NYLANDER, 1857

New data: M. Rosso, Etna, Castiglione di Sicilia (CT), 1,740 m, Fagus sylvatica woods, 10 Oct 1992, A. AliCATA lgt., AACI.

Global distribution: Western European.

Notes: The species was already known in peninsular Italy (RADCHENKO \& ELMES 2010). The Sicilian record represents the new southernmost known point of distribution of M. lobulicornis. Some of its intraspecific forms may represent good species which are yet to be recognized (RADCHENKO \& ELMES 2010). The Sicilian samples were identified by Graham W. ELMES.

\section{Nylanderia $\mathrm{sp} .1$}

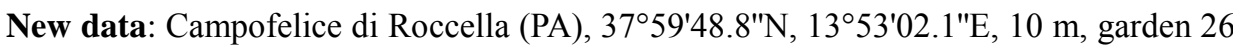
Aug 2014, E. SCHIFANi lgt, ESPI. Palermo, Orto Botanico dell'Università di Palermo, $38^{\circ} 06^{\prime} 43^{\prime \prime N}, 13^{\circ} 22^{\prime} 22^{\prime \prime E}, 10$ m, garden, Sept 2016, E. SCHIFANI lgt, ESPI.
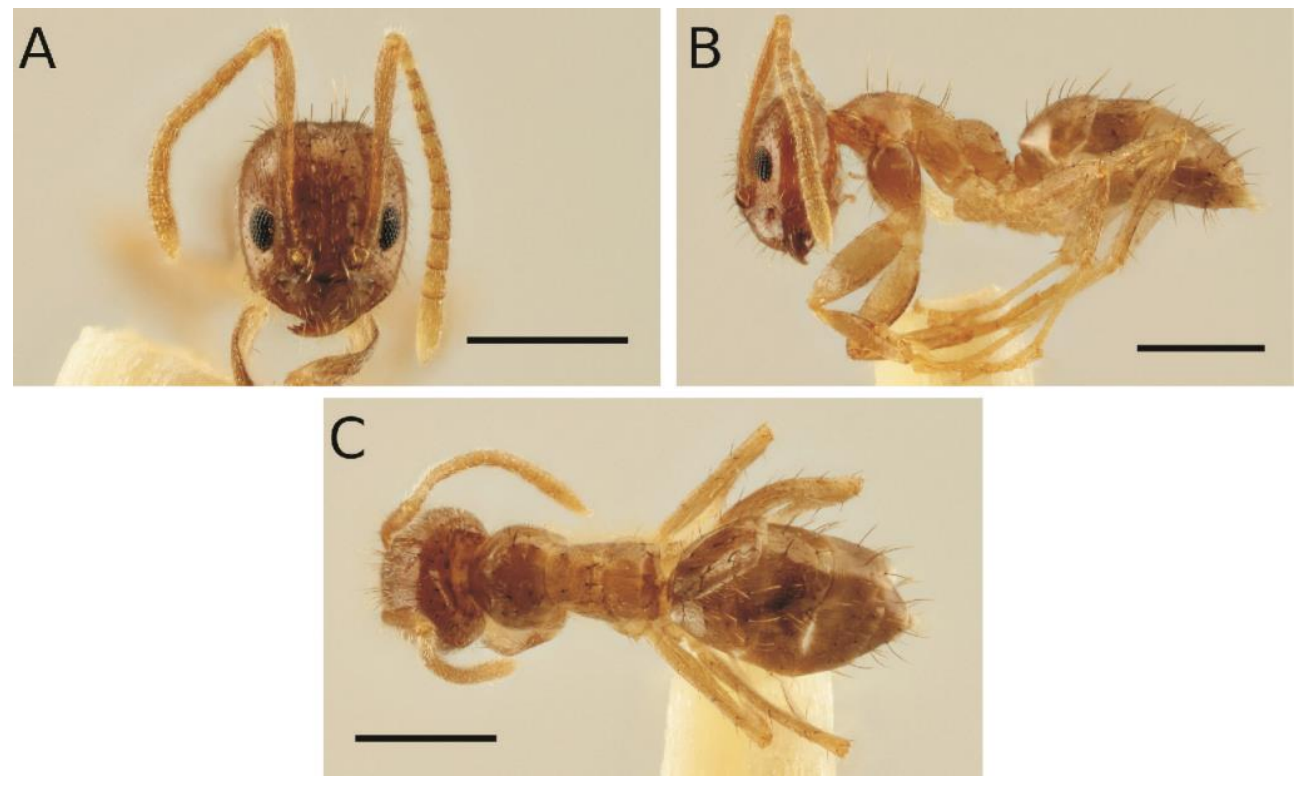

Fig. 2. Nylanderia sp. 1 worker from Campofelice di Roccella (PA) in head (A), lateral (B) and dorsal view (C). Scale bar: $0.5 \mathrm{~mm}$. Photos by Enrico SCHIFANI. 



Fig. 3. Nylanderia sp. 2 worker from Mondello (PA) in head (A), lateral (B) and dorsal view (C). Scale bar: $0.5 \mathrm{~mm}$. Photos by Enrico SCHIFANI.

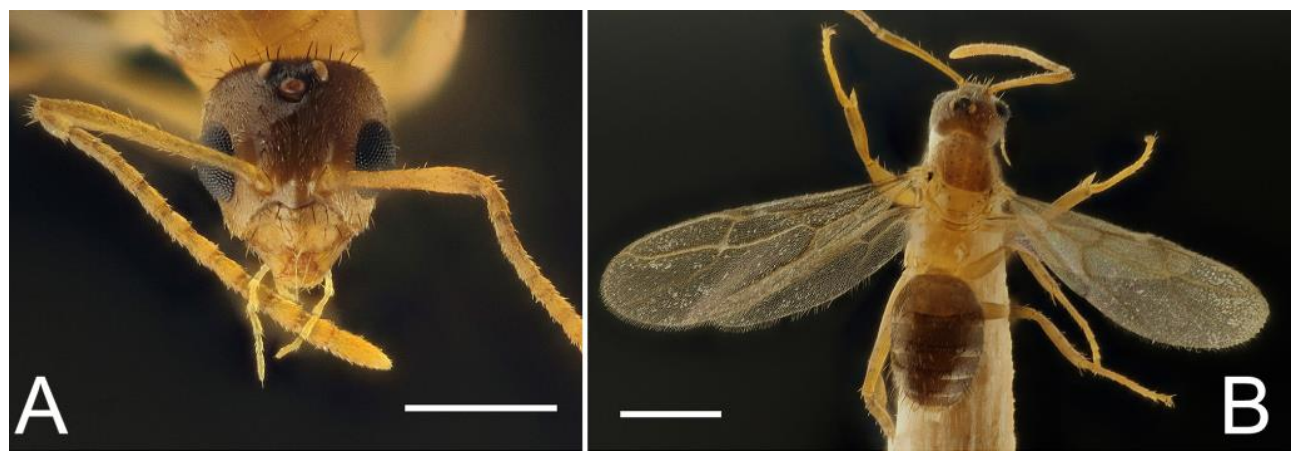

Fig. 4. Nylanderia sp. 2 male from Mondello (PA) in head (A) and dorsal view (B). Scale bar: $0.5 \mathrm{~mm}$. Photos by Enrico SCHIFANI.

Notes: Nylanderia EMERY, 1906 is a large cosmopolitan genus of great ecological importance; it is host to several tramp species (LAPOLLA et al. 2011a). Unfortunately, it has historically lacked a global taxonomic revision; this has led to a situation where species identification in many cases is problematic if not impossible (LAPOLLA et al. 2011a). Even 
though some recent steps have considerably improved the situation, this problem still persists and for this reason some of our samples are treated here as morphospecies. $N$. bourbonica (FOREL, 1886) was the only species of the genus known to be present in Italy, where it has only been detected indoors (JUCKER et al. 2008). No species of Nylanderia has been recorded in Sicily before. Workers of Nylanderia sp. 1 (Fig. 2) were observed foraging only on the ground.

\section{Nylanderia sp. 2}

New data: Palermo, Mondello, $38^{\circ} 11^{\prime} 43.2^{\prime \prime} \mathrm{N}, 13^{\circ} 20^{\prime} 07.2^{\prime \prime} \mathrm{E}, 5 \mathrm{~m}$, garden and indoors, 20 Apr 2016, E. SCHIFANI lgt, ESPI. Palermo, Orto Botanico dell'Università di Palermo, $38^{\circ} 06^{\prime} 43^{\prime \prime N}, 13^{\circ} 22^{\prime} 22^{\prime \prime E}, 10 \mathrm{~m}$, garden, Sept 2016, E. SCHIFANI lgt, ESPI. Palermo, Mondello, 38 $10^{\prime} 59.8^{\prime \prime N}, 13^{\circ} 19^{\prime} 31.4^{\prime \prime} \mathrm{E}, 25 \mathrm{~m}$, garden, 18 Apr 2017, E. SCHIFANI lgt, ESPI. Palermo, Addaura, $38^{\circ} 11^{\prime} 24.5^{\prime \prime} \mathrm{N}, 13^{\circ} 20^{\prime} 41.8^{\prime \prime} \mathrm{E}, 15 \mathrm{~m}$, males attracted by artificial lights in an urban area, 23 Jun 2017, E. SCHIFANI lgt, ESPI. Palermo, 38 $07^{\prime} 29.2^{\prime \prime N}, 13^{\circ} 21^{\prime} 03^{\prime \prime E}, 20$ $\mathrm{m}$, indoors, 7 Dec 2017, E. GENDUso lgt, ESPI. Palermo, 38 $8^{\circ} 10^{\prime} 10.2^{\prime \prime N} 13^{\circ} 19^{\prime} 03.3^{\prime \prime E}, 45$ m, garden, 3 Sept 2018, E. SCHIFANI lgt, ESPI.

Notes: See the comments relating to Nylanderia sp. 1. Nylanderia sp. 2 workers (Fig. 3) were found active outdoors almost throughout the year, always foraging on the ground, while numerous males were found to have been attracted to lights during June (Fig. 4).

\section{Nylanderia jaegerskioeldi (MAYR, 1904)}

New data: Campofelice di Roccella (PA), 37 $59^{\prime} 48.4^{\prime \prime} \mathrm{N}, 13^{\circ} 53^{\prime} 02.1^{\prime \prime E}, 10 \mathrm{~m}$, garden, 26 Aug 2014, E. SChIFANI lgt, ESPI. Castellammare del Golfo (TP), 17 Feb 2016, R. BLATRIX lgt, RBMF. Palermo, Orto Botanico dell'Università di Palermo, garden, 11 Apr 2018, E. SCHIFANI lgt, ESPI.

Global distribution: A species of African origin but spreading quickly across the Mediterranean (LAPOLLA et al. 2011b, GÓMEZ 2017).

Notes: According to Antmaps, its presence is considered native in Sub-Saharan Africa and in the Near East (including the Arabian peninsula and Mediterranean countries from Syria to Libya). However, the exact boundaries of its native range are still not well defined. It has recently been collected in Pantelleria (Lago di Venere, 3.viii.2018, M. PAVESI lgt, MSNM, Fabrizio RigATO pers. comm.). In Sicily, $N$. jaegerskioeldi seems to be an introduced species restricted to anthropogenic habitats. The workers of $N$. natalensis (FOREL, 1915) are morphologically indistinguishable from those of $N$. jaegerskioeldi (LAPOLLA et al. 2011b), but the latter is considered to be restricted to Southern Africa (LAPOLLA et al. 2011b). N. jaegerskioeldi was noted to displace native ants in the areas it occupies (SAlATA et al. 2018). Aggressive interactions against Pheidole pallidula (NYLANDER, 1849) were noted in Campofelice di Roccella. 
Other material of Nylanderia sp.

New data: Marausa (TP), $37^{\circ} 55^{\prime} 43.8^{\prime \prime} \mathrm{N}, 12^{\circ} 29^{\prime} 05.7^{\prime \prime} \mathrm{E}, 3 \mathrm{~m}$, queen attracted by artificial lights in a garden, 7 Sept 2017, L. BARRACO lgt, ESPI. Catania (CT), males attracted by artificial lights in a garden, 12 Jun 2018, A. ALICATA lgt., AACI.

Notes: A single winged queen (Fig. 2D-F) from Marausa could not be identified as no key for queens exists and the queens of many taxa are still undescribed. Several males collected in Catania clearly differ from those of Nylanderia sp. 2 in their genitalia, but they could not be identified for the same reasons as the queen. Overall, this material could either belong to one of the aforementioned morphospecies, to $N$. jaegerskioeldi, or even to some other, as yet unrecorded entities.

20. Paratrechina longicornis (LATREILLE, 1802)

New data: Capo Mulini (CT), Apr 2002 and Jul 2015, A. ALICATA lgt, tourist area near a beach as well as an indoor colony, AACI. Siracusa, $37^{\circ} 03^{\prime} 53.9^{\prime \prime} \mathrm{N}, 15^{\circ} 17^{\prime} 24.9^{\prime \prime} \mathrm{E}, 5 \mathrm{~m}$,

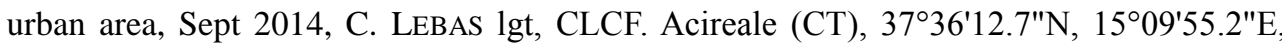
$125 \mathrm{~m}$, railroad tracks, Dec 2017, E. Genduso lgt, ESPI. Palermo, 38 $06^{\prime} 12^{\prime \prime} \mathrm{N}$, $13^{\circ} 21^{\prime} 18.9^{\prime \prime E}, 40 \mathrm{~m}$, outside the hospital building, 20 Jan 2017, M. PECORARO lgt, ESPI.

Global distribution: An invasive species, probably native to Southeast Asia, and now arguably the most widespread ant species in the world as a result of human activities (WETTERER 2008).

Notes: $P$. longicornis is known for its ability to invade disturbed or completely artificial environments and displace native ant species, but rarely does so in natural ecosystems, especially if far from the tropical region (WETTERER 2008). For example, within the Mediterranean region its presence has been considered to represent only a minimal threat in the Iberian Peninsula (ESPADALER \& COLLINGWOOD 2000), whereas it is of much greater concern in the Canary Islands (ESPADALER \& BERNAL 2003, SCHIFANI et al. 2018). Nearby records are those from Malta (SCHEMBRI \& COLLINGWOOD 1981, GóMEZ 2017), while in peninsular Italy it has only been recorded as an indoor pest species (SÜSS 1979; SCHEMBRI \& ColLINGWOOD 1981 probably refer to Süss 1979). The records from Capo Mulini prove that the species is well established there, having occupied the same areas for at least 14 years. Despite being a thermophilous species, in Acireale workers were still found actively foraging and tending aphids in the middle of December (Emanuele GENDUSO pers. comm.) and in Palermo an active foraging trail, even though made up of just a few slow-moving ants, was observed in January around the coldest times of the year (Marco PECORARO pers. comm.). 
21. Pheidole indica MAYR, 1879

New data: Etna (CT), 3741'28.6"N, 1501'15.8'E, 1,650 m, Sept 2014, C. LEBAS lgt, CLCF. Palermo, 38 $06^{\circ} 38.3^{\prime \prime N}, 13^{\circ} 22^{\prime} 04.5^{\prime \prime} \mathrm{E}, 15 \mathrm{~m}$, urban area, 6 Aug 2016, E. SCHIFANI lgt, ESPI. Palermo, $38^{\circ} 06^{\prime} 22.4^{\prime \prime N} 13^{\circ} 21^{\prime} 05.7^{\prime \prime E}, 45 \mathrm{~m}$, urban area, 6 July 2017, E. SCHIFANI lgt, ESPI.

Global distribution: The Mediterranean populations of this globally distributed species, native to Asia, were known under the name of P. teneriffana FOREL, 1893 until recently (SARNAT et al. 2015).

Notes: P. indica was also found in Eastern Sicily in 1992 (Andrea SALVARANI pers. comm.) and was recorded in Pantelleria (MEI 1995) and Malta (BARONI URBANI 1968, GÓMEZ 2017). The species is not considered a major pest (WETTERER 2011a); it is often only collected in disturbed areas in the Mediterranean region (e.g. BARONI URBANI 1968, GÓMEZ \& ESPADALER 2006).

22. Proceratium numidicum SANTSCHI, 1912

New data: Gibilmanna (PA), oak forest, 28 May 1996, F. ANGELINI lgt., sifting soil and litter, AACI.

Global distribution: Maghreb, Balkans, Turkey, Cyprus (BARONI URBANI \& DE ANDRADE 2003).

Notes: The third species of this rare genus to be found in Sicily, it is new to Italy (BARONI URBANI \& DE ANDRADE 2003).

23. Stenamma petiolatum EMERY, 1897

New data: Monte Inici, 800 m, Quercus ilex woods, Castellammare del Golfo (TP), 3 Mar 1994, A. AliCATA lgt. AACI. Bosco del Fanuso, Bosco della Ficuzza (PA), 3751'34.47"N, 1325'30.37"E, deciduous Quercus woods, 980 m, 24 May 1996, A. ALICATA lgt, AACI.

Global distribution: A rarely collected Italian endemic (RIGATO 2011).

Notes: The species was reported as doubtfully present in Sicily by POLDI et al. (1995), and never confirmed (although generically reported to be present in Sicily by GALKOWSKI 2008). The Maltese records by SCHEMBRI \& COLLINGWOOD (1981) are also dubious (RIGATO 2011).

24. Stigmatomma denticulatum RoGER, 1859

New data: RNI Grotta Monello (SR), pitfall trap, 22 May 1991, CARUSO lgt, AACI.

Global distribution: A rarely collected species known from the Mediterranean region and east to Turkmenistan. 
Notes: S. denticulatum was already known in Italy but was never recorded before from the southern regions (MEI 1992). Also known from Malta (SCHEMBRI \& COLLINGWood 1981).

25. Strongylognathus testaceus (SCHENCK, 1852)

New data: Madonie (PA), 3752'01"N, 1404'01.6"E, 1,215 m, meadow, 10 Jun 2016, E. SCHIFANI lgt, ESPI.

Host: Two workers were found under a stone within a colony of Tetramorium indocile SANTSCHI, 1927 (see below), representing the first reported case of such interaction (see WAGNER et al. 2017).

Global distribution: From Europe to Central Asia.

Notes: SANETRA et al. (1999) updated the distribution of S. testaceus in southern peninsular Italy peninsula (Calabria); it also occurs in Sardinia. This species is considered threatened in many European countries, but is not on the IUCN Red List (MABELIS 2007).

26. Strumigenys tenuipilis EMERY, 1915

New data: RNI Grotta Monello (SR), pitfall trap, 23 Apr 1991, CARUSO lgt, AACI.

Global distribution: Mediterranean.

Notes: S. tenuipilis was known in Italy but with no records from the southern regions (MEI 1992). It is rarely collected and its distribution appears discontinuous (FANCELLO \& LEO 1991).

27. Tapinoma madeirense FOREL, 1895

New data: Palermo, Mondello, $38^{\circ} 11^{\prime} 43.2^{\prime \prime} \mathrm{N}, 13^{\circ} 20^{\prime} 07.2^{\prime \prime} \mathrm{E}, 5$ m, garden, 30 Feb 2016,

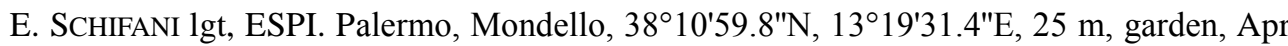
2017, E. SCHIFANI lgt, ESPI.

Global distribution: Mediterranean Europe.

Notes: In Italy T. madeirense was known only from Sardinia (RIGATO \& TONI 2011). It is to be noted that all specimens were collected in anthropogenic habitats represented by gardens with Citrus L. orchards and never in natural habitats, a potential indication that this species is exotic in Sicily. Males (which according to SEIFERT 2012b allow a safe morphological identification) were not found. Instead, the identification was performed by analysing the mtCOI gene (M. CENTORAME Sapienza University).

28. Temnothorax affinis (MAYR, 1855)

New data: Sovareto (AG), 37²9'47.5"N, 1307'27.3"E, 40 m, olive orchard, Apr 2009, C. GALKOWSKI lgt, CGSF.

Global distribution: A species widespread in Europe and east towards Caucasus. 
Notes: T. affinis was already known from Italy (EMERY 1916) and Sardinia (RIGATO \& TONI 2011). Workers were observed running in tandem on olive trees (Cristophe GALKOWSKI pers. comm.).

\section{Tetramorium bicarinatum (NYLANDER, 1846)}

New data: Casa delle Farfalle, Dept. Anim. Biol. Catania, butterfly house, 5 Jul 2006,

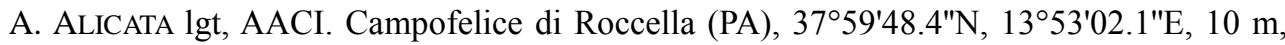
garden 29 Sept 2014, E. SCHIFANI lgt, EPSC. Palermo, Mondello, 38¹2'01.8"N, $13^{\circ} 18^{\prime} 07^{\prime \prime E}, 30 \mathrm{~m}$, garden, 12 Aug 2016, E. SCHIFANI lgt, ESPI.

Global distribution: T. bicarinatum is a well-known worldwide tramp ant native to the Indo-Pacific region (WETTERER 2009). Its presence was already known in mainland Italy (LIMONTA \& COLOMBO 2003, JUCKER et al. 2008, BOROWIEC \& SALATA 2015) and recently in Malta (GómEZ 2017).

Notes: The species is not considered to be a major pest (WETTERER 2009), but was noted to displace native species from the areas it occupies (SALATA et al. 2017). Foraging was observed in large groups both on the ground and on Citrus trees. Workers were active out of the nests both during the day and at night at least in August, forming large aggregations and trails. In Campofelice di Roccella, winged queens were collected in September in a satellite nest under a jar, where they were hiding together with a small group of workers (nests of T. bicarinatum tend to be widely distributed, ASTRUC et al. 2001).

30. Tetramorium caespitum (LINNAEUS, 1758)

New data: Nebrodi (ME), M. Soro, 3756'35.5"N, 1440'23.6"E, 1,440 m, meadow, 7 Aug 2016, E. SCHIFANI lgt, ESPI. Bosco della Ficuzza (PA), 37051'26.8"N, 13²5'23.3"E, 1,060 m, meadow, 27 Nov 2017, E. SCHIFANI lgt, ESPI. Madonie (PA), 37050'44.3"N, $14^{\circ} 02^{\prime} 41.2^{\prime \prime E}, 1,655 \mathrm{~m}$, meadow, Sept 2017, E. GENDUSO lgt, ESPI.

Global distribution: Europe and Caucasus (WAGNER et al. 2017).

Notes: Although already recorded many times in Sicily in the past, T. caespitum was later discovered to be a difficult complex of several cryptic species rather than a single one (SCHLICK-STEINER et al. 2006). Because of this situation, these species were not named until recently (WAGNER et al. 2017). Among them, only T. alpestre STEINER, SCHLICKSTEINER \& SEIFERT, 2010 and T. immigrans SANTSCHI, 1927 were known to be present in Sicily (WAGNER et al. 2017), but at least a third species was suspected (SANETRA et al. 1999). T. caespitum was already known from peninsular Italy and Sardinia (WAGNER et al. 2017). Unlike other parts of Europe, species of the caespitum complex do not usually occur from low to mid altitudes in Sicily. The only exception is represented by the most likely alien T. immigrans, which seems to be restricted to cities and anthropogenic areas (see also 
SANETRA et al. 1999).

31. Tetramorium indocile SANTSCHI, 1927

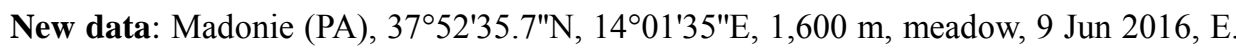

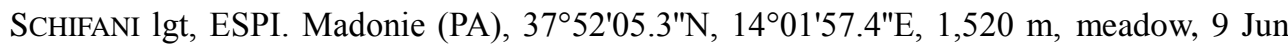
2016, E. SCHIFANI lgt, ESPI.

Global distribution: Present from Kyrgyzstan to Iberia.

Notes: A recently recognized species (CSÖSZ et al. 2014); see also the comments on $T$. caespitum. T. indocile was already known in the southern Italian peninsula (WAGNER et al. 2017).

32. Tetramorium lanuginosum MAYR, 1870

New data: Trapani, $38^{\circ} 00^{\prime} 57.8^{\prime \prime} \mathrm{N}, 12^{\circ} 31^{\prime} 07.2^{\prime \prime E}, 2$ m, garden, Sept 2014, C. LEBAS lgt, CLCF.

Global distribution: Another tramp species which has spread over all the continents as a result of human activities but without becoming a serious pest (WETTERER 2010a). It is native to Asia and possibly parts of Oceania (WETTERER 2010a).

Notes: Its presence was already known in Malta (SCHEMBRI \& COLLINGwood 1981; 1995) but it is new to Italy.

\section{DISCUSSION}

The majority of the newly recorded species appears to be native. These species may have been missed by previous surveys, either because they were simply not found (especially in view of the notorious difficulties involved in collecting inquiline social parasites like Strongylognathus testaceus or endogean species like Stigmatomma denticulatum and Strumigenys tenuipilis), or because they were previously taxonomically unrecognized (e.g. Lasius lasioides, Tetramorium indocile). On the other hand, at least seven species are clearly exotic and known worldwide as tramp or invasive species, while some others may have been introduced from adjacent regions. Although at the present time none of these introduced species seems to be particularly threatening to native ecosystems, such an uncontrolled influx of exotic fauna is nonetheless worrying and the scale of its ecological impact in the future remains unpredictable.

Only three other evidently alien ants have been identified in Sicily so far: the Argentine ant Linepithema humile, first recorded around a century ago by DONISTHORPE (1927), Tetramorium immigrans, possibly introduced a long time before its recent 
identification (WAGNER et al. 2017), and Hypoponera punctatissima (ROGER, 1859) (BOLTON \& FISHER 2011; the identity of this record has to be verified according to SEIFERT SEIFERT 2013). The geographic origin of Strumigenys membranifera EMERY, 1869, recorded by LA PERGOLA et al. (2008), is as yet unclear (WETTERER 2011b), however it is usually regarded as exotic in the Mediterranean basin (e.g. SALATA et al. 2018, TAHERI \& REYESLÓPEZ 2018). The case of Aphaenogaster splendida (ROGER, 1859) is also somewhat puzzling: it has been collected exclusively in cities or other anthropogenic areas in Sicily (SCUPOLA 2017, authors' unpublished data) and could be another introduced species. However, its crepuscular habits and inconspicuous nest entrances make it hard to discover; in the absence of targeted searches, this may have biased knowledge of its distribution within natural habitats. In addition, A. splendida has been found in natural habitats, an evergreen oak wood and a garrigue, in Malta and Lampedusa respectively (authors' unpublished data).

Among the many species introduced across the world, only a few have had significant success in spreading outside the human-modified habitats where they first arrive, but the ones that do so may have severe impacts on local ecosystems and human activities (HoLWAY et al. 2002). Moreover, ongoing changes in the environment, including climate, are expected to alter the invasiveness potential of many ant species (BERTELSMEIER et al. 2014). If eradication does not occur within a short time after introduction, well-established populations can easily prove to be very difficult or impossible to remove (HOLWAY et al. 2002). The finding of all three species/morphospecies of Nylanderia in a botanical garden in Palermo, that of Tetramorium bicarinatum inside a butterfly house and other findings within private gardens suggest once again that the transfer of living plants or soil may play a significant role in the spread of exotic ants.

At the present time, four ant species of Sicily have been placed on the IUCN Red List, where they are considered Vulnerable (IUCN 1996): Plagiolepis grassei LE MASNE, 1956, Strongylognathus alpinus WHEELER, W.M., 1909, S. destefanii EMERY, 1915 and Temnothorax muellerianus (FINZI, 1922). Since they are all inquiline social parasites, whose lifestyle makes them difficult to detect during field surveys, they may be perceived as rarer than they actually are and their distributional range may be underestimated (ESPADALER \& LÓPEZ-SORIA 1991, SCHIFANI 2017). While many European social parasite ants have been classified as Vulnerable in the IUCN Red List, a satisfactory understanding of their conservation status is still far from being reached, with only few indications available (e.g. TRONTTI et al. 2006, MABELIS 2007).

In conclusion, with the addition of a total of 32 new elements, the present study fills a significant gap, notably increasing (by about 25\%) the number of taxa recorded for the Sicilian myrmecofauna, which now stands at about 150 . However, in order to produce a reliable checklist for Sicily, additional efforts are still required. A considerable number of 
past records have to be carefully verified and many listed species are probably not truly present. In addition, many species groups need to be taxonomically revised. Finally, areas are almost completely unexplored (e.g. provinces of Enna and Caltanissetta), thus giving an incomplete picture of the species distribution and increasing the chances of discovering further taxa.

\section{ACKNOWLEDGEMENTS}

We are indebted to Rumsaïs BLATRIX (Antarea and Centre d'Écologie Fonctionnelle et Évolutive - CNRS, Montpellier, France), Cristophe GALKOwSKI (Antarea, France) and Claude LEBAS (Antarea, France) for adding to this study their respective unpublished data obtained from their visits to Sicily. We are also grateful to Maurizio MeI (Sapienza University, Rome, Italy) for showing us his original drawings of Leptanilla poggii in order to assist our identification and to Massimiliano Centorame (Sapienza University, Rome, Italy) to provide us with a molecular identification of the Tapinoma madeirense material. We also thank Luigi Barraco, Luca Bertoni, Emanuele Genduso, Marco Pecoraro, Roberto VIVIANO and Salvatore TOMARCHIO for collecting and sending us Sicilian ant specimens, some of which were included in the present study, and Lech BOROWIEC (University of Wroclaw, Poland) for searching the ant collection at the Department of Biodiversity and Evolutionary Taxonomy of the University of Wroclaw for Sicilian specimens.

\section{REFERENCES}

ANTMAPS. Available from: www.antmaps.org. Accessed 27 July 2018.

ANTwEB. Available from: https://www.antweb.org/taxonomicPage.do?rank=species\&adm1 Name= Sicilia\&countryName=Italy. Accessed 27 July 2018.

Astruc C., MAlosse C., ERRARd C. 2001. Lack of intraspecific aggression in the ant Tetramorium bicarinatum: a chemical hypothesis. Journal of Chemical Ecology, 27 (6): 1229-1248.

Baroni Urbani C. 1964. Studi sulla mirmecofauna d'Italia. II. Formiche di Sicilia. Atti dell Accademia Gioenia di Scienze Naturali in Catania, 16: 25-66.

BARONI URBANi C. 1968. Studi sulla mirmecofauna d'Italia. IV. La fauna mirmecologica delle isole Maltesi ed il suo significato ecologico e biogeografico. Annali del Museo Civico di Storia Naturale "Giacomo Doria", 77: 408-559.

Baroni Urbani C. 1971. Catalogo delle specie di Formicidae d'Italia. Memorie della Società Entomologica Italiana, 50: 5-287. 
Baroni Urbani C., De ANDRADE M.L. 2003. The ant genus Proceratium in the extant and fossil record (Hymenoptera: Formicidae). Museo Regionale di Scienze Naturali, Monografie, 36: 1-492.

Bertelsmeier C., Luque G.M., Hoffmann B.D., ChOuRChamp F. 2014. Worldwide ant invasions under climate change. Biodiversity and Conservation, 24 (1): 117-128.

BOLTON B. \& FISHER B. L. 2011. Taxonomy of Afrotropical and West Palaearctic ants of the ponerine genus Hypoponera SANTSCHI (Hymenoptera: Formicidae). Zootaxa, 2843 (1): 1-118.

BOROwIEC L. 2014. Catalogue of ants of Europe, the Mediterranean Basin and adjacent regions (Hymenoptera: Formicidae). Genus, 25 (1-2): 1-340.

Borowiec L., Salata S. 2012. Ants of Greece - Checklist, comments and new faunistic data (Hymenoptera: Formicidae). Genus, 23 (4): 461-563.

Borowiec L., Salata S. 2015. Pheidole symbiotica Wasmann, 1909, an enigmatic supposed social parasite, is a nematode-infested form of Pheidole pallidula (NYLANDER, 1849) (Hymenoptera: Formicidae: Myrmicinae). Sociobiology, 62 (2): 181-186.

BRAČKO G. 2017. First discoveries of colonies of the rare ant species Camponotus tergestinus MüLlER, 1921 (Hymenoptera: Formicidae) in situ. Natura Sloveniae, 19 (2): 5-14.

BusChINGER A., EHRHARDT W., FisCHER K., OFER J. 1988. The slave-making ant genus Chalepoxenus (Hymenoptera, Formicidae). I. Review of literature, range, slave species. Zoologische Jahrbücher. Abteilung für Systematik, Ökologie und Geographie der Tiere, 115: 383-401.

Collingwood C.A. 1963. Notes on some South European and Mediterranean ants. Entomologist's Record and Journal of Variation, 75: 114-119.

Csősz S., Wagner H. C., Bozsó M., Seifert B., Arthofer W., Schlick-Steiner B. C., Steiner F. M., PÉnZES Z. 2014. Tetramorium indocile SANTSCHI, 1927 stat. rev. is the proposed scientific name for Tetramorium sp. C sensu SCHLICK-STEINER et al. (2006) based on combined molecular and morphological evidence (Hymenoptera: Formicidae). Zoologischer Anzeiger, 253 (6): $469-481$.

DONISTHORPE H. 1927. The ants (Formicidae), and some myrmecophiles, of Sicily. Entomologist's Record and Journal of Variation, 39: 6-9.

EMERY C. 1915. Contributo alla conoscenza delle formiche delle isole italiane. Descrizione di forme mediterrannee nuove o critiche. Annali del Museo Civico di Storia Naturale di Genova, 6 (3): 244-270.

EMERY C. 1916. Fauna entomologica italiana. I. Hymenoptera.-Formicidae. Bollettino della Società entomologica italiana, 47: 79-275.

EMERY C. 1925. Les espèces européennes et orientales du genre Bothriomyrmex. Bulletin de la Société Vaudoise des Sciences Naturelles, 56: 5-22.

ESPADALER X., Bernal V. 2003. Exotic ants in the Canary Islands (Hymenoptera, Formicidae). Vieraea, 31: 1-7.

Espadaler X., Collingwood C.A. 2000. Transferred ants in the Iberian Peninsula. Nouvelle Revue d'Entomologie, 17 (3): 257-263.

ESPADALER X., LÓPEZ-SORIA L. 1991. Rareness of certain Mediterranean ant species, fact or artifact? Insectes Sociaux, 38 (4): 365-377. 
Fancello L., Leo P. 1991. Le attuali conoscenze sui formicidi dacetini di Sardegna e Sicilia (Hymenoptera, Formicidae). Bollettino dell' Associazione Romana di Entomologia, 45: 125-129.

Fauna EuropaEa. Available from: fauna-eu.org. Accessed 27 December 2017.

FINZI B. 1930. Contributo allo studio degli Aphaenogaster paleartici (Formicidae-Myrmicinae). Bollettino della Società entomologica italiana, 62 (8): 151-156.

GALKOWSKI C. 2008. Quelques fourmis nouvelles ou intéressantes pour la faune de France (Hymenoptera, Formicidae). Bulletin de la Société Linnéenne de Bordeaux, 36 (4): 423-433.

Galkowski C., CAGNiAnt H. 2017. Contribution à la connaissance des fourmis du groupe angustulus dans le genre Temnothorax (Hymenoptera, Formicidae). Revue de l'Association Roussillonnaise d'Entomologie, 26 (4): 180-191.

Glaser F., Freitag A., Martz H. 2012. Ants (Hymenoptera: Formicidae) in the Münstertal (Val Müstair) - a hot spot of regional species richness between Italy and Switzerland. Gredleriana, 12: $273-284$.

GómEz K. 2017. Two species of exotic ants (Hymenoptera: Formicidae) new to Malta. Boletín de la Sociedad Entomológica Aragonesa, 61: 233-235.

GÓMEZ K., EspadAler X. 2006. Exotic ants in the Balearic Islands. Myrmecologische Nachrichten, 8: $225-233$.

Holway D.A., Lach L., Suarez A.V., Tsutsui N.D., CASE T. J. 2002. The causes and consequences of ant invasions. Annual Review of Ecology and Systematics, 33: 181-233.

IUCN 1996. IUCN Red List of Threatened Animals. IUCN, Gland, Switzerland.

JANicki J., NARUla N., Ziegler M., GuÉNARD B., ECONOMO, E. P. 2016. Visualizing and interacting with large-volume biodiversity data using client-server web-mapping applications: The design and implementation of antmaps.org. Ecological Informatics, 32: 185-193.

Jucker C., Rigato F., Regalin R. 2008. Exotic ant records from Italy (Hymenoptera Formicidae). Bollettino di Zoologia agraria e di Bachicoltura, 40 (1): 99-107.

KUTter H. 1977. Fauna Insecta Helvetica 6. Hymenoptera: Formicidae. Schweizerische Entomologische Gesellschaft, Zürich.

LA GRECA M. 1957. Considerazioni sull'origine della fauna siciliana. Bollettino di Zoologia, 24: 593-631.

La Pergola A., Alicata A., Longo S. 2008. Survey of the ants (Hymenoptera Formicidae) in citrus orchards with different types of crop management in Sicily. IOBC/wprs Bulletin, 38: 233-237.

LaPolla J.S., Brady S.G., Shattuck S.O. 2011a. Monograph of Nylanderia of the world: an introduction to the systematics and biology of the genus. Zootaxa, 3110: 1-9.

LaPolla J.S., Hawkes P.G., Fisher B. L. 2011b. Monograph of Nylanderia (Hymenoptera: Formicidae) of the World, Part I: Nylanderia in the Afrotropics. Zootaxa, 3110: 10-36.

Limonta L., Colombo M. 2003. Record of Pheidole megacephala (F.), Pheidole nodus SMith and Tetramorium bicarinatum NYLANDER (Hymenoptera, Formicidae), tropical species, in nursery imported plants. Bollettino di Zoologia agraria e di Bachicoltura, 35: 287-289.

MABELIS A.A. 2007. Do ants need protecting? Entomologische Berichten, 67 (4): 145-149. 
Massa B., Sbordoni V., Vigna Taglianti A. 2011. La Biogeografia della Sicilia: considerazioni conclusive sul XXXVII Congresso della Societa'Italiana di Biogeografia Biogeographia - The Journal of Integrative Biogeography, 30: 685-694.

MeI M. 1992. Su alcune specie endogee o criptobiotiche della mirmecofauna italiana. Fragmenta Entomologica, 23: 411-422.

MeI M. 1995. Hymenoptera Formicidae (con diagnosi di due nuove specie). Arthropoda di Lampedusa, Linosa e Pantelleria. Il Naturalista siciliano, 19: 753-772.

Mitroiu M.D., Noyes J., Cetkovic A., Nonveiller G., Radchenko A., Polaszek A., Ronquist F., Forshage M., Pagliano G., Gusenleitner J., Bartalucci M., Olmi M., Fusu L., Madl M., Johnson N., Jansta P., Wahis R., Soon V., Rosa P., Osten T., Barbier Y., De Jong Y. 2015. Fauna Europaea: Hymenoptera - Apocrita (excl. Ichneumonoidea). Biodiversity Data Journal, 3 : e4186.

Muscarella C., Baragona A. 2017. The endemic fauna of the Sicilian islands. Biodiversity Journal, 8 (1): 249-278.

Poldi B., Mei M., Rigato F. 1995. Hymenoptera Formicidae. [in:] A. Minelli, S. Ruffo, S. LA Posta (eds). Checklist delle Specie della Fauna Italiana, Calderini, Bologna, 1-10.

RAdChEnko A.G., Elmes G. W. 2010. Myrmica Ants (Hymenoptera: Formicidae) of the Old World. Natura Optima Dux Foundation, Warsaw.

Rigato F. 2011. Contributions to the taxonomy of West European and North African Stenamma of the westwoodii species-group. (Hymenoptera Formicidae). Memorie della Società Italiana di Scienze Naturali e del Museo Civico di Storia Naturale di Milano, 37: 1-56.

Rigato F., Toni I. 2011. Short notes 21. Hymenoptera, Formicidae. [in:] G. NARDi, D. WhitMore, M. Bardiani, D. Birtele, F. Mason, L. Spada, P. Cerretti (eds.). Biodiversity of Marganai and Montimannu (Sardinia). Research in the framework of the ICP Forests network. Conservazione Habitat Invertebrati, 5. Sommacampagna, Cierre Edizioni, Verona, 873-882.

Salata S., Georgiadis C., BorowiEC L. 2018. Invasive ant species (Hymenoptera: Formicidae) of Greece and Cyprus. North-Western Journal of Zoology: e171204.

SANETRA M., Gusten R., Schulz A. 1999. On the taxonomy and distribution of Italian Tetramorium species and their social parasites (Hymenoptera, Formicidae). Memorie della Società Entomologica Italiana, 77: 317-357.

SARnat E.M., Fischer G., Guenard B. \& ECONOMo E.P. 2015. Introduced Pheidole of the world: taxonomy, biology and distribution. Zookeys, 543: 1-109.

Schär S., Talavera G., Espadaler X., Rana J.D., Andersen A., Cover S.P., Vila R. 2018. Do Holarctic ant species exist? Trans-Beringian dispersal and homoplasy in the Formicidae. Journal of Biogeography, 45 (8): 1-12.

SCHEMBRi S.P., Collingwood C.A. 1981. A revision of the myrmecofauna of the Maltese Islands (Hymenoptera, Formicidae). Annali del Museo Civico di Storia Naturale "Giacomo Doria", 83: 417-442.

SCHEMBRi S.P., Collingwood C.A. 1995. The myrmecofauna of the Maltese islands. Notes and additions. Bollettino della Società Entomologica Italiana, 127 (2): 153-158.

SCHIFANi E. 2017. First record of the vulnerable social parasite ant Plagiolepis grassei in Italy (Hymenoptera: Formicidae). Fragmenta Entomologica, 49 (1): 61-64. 
Schifani E., Gentile V., Scupola A., Espadaler X. 2018. Yet another alien: a second species of Lepisiota SANTSCHI 1926 (Hymenoptera: Formicidae) spreading across the Canary Islands (Spain). Fragmenta Entomologica, 50 (1): 61-64.

Schlick-Steiner B.C., Steiner F.M., Moder K., Seifert B., Sanetra M., Dyreson E., Stauffer C., Christian E. 2006. A multidisciplinary approach reveals cryptic diversity in Western Palearctic Tetramorium ants (Hymenoptera: Formicidae). Molecular Phylogenetics and Evolution, 40 (1): 259-273.

SCUPOla A., Ballarin R. 2009. The genus Leptanilla EMERY, 1870 in Sicily (Hymenoptera: Formicidae). Myrmecologische Nachrichten, 12: 129-132.

Scupola A. 2009. Le specie italiane del genere Cardiocondyla (Hymenoptera Formicidae). Bollettino della Società entomologica italiana, 141 (3): 187-190.

Scupola A. 2017. Aphaenogaster muelleriana Wolf, 1915 (Hymenoptera Formicidae) in Salento (South East Italy). Biodiversity Journal 8 (1): 3-8.

SEIFERT B. 1992. A taxonomic revision of the Palaearctic members of the ant subgenus Lasius s. str. (Hymenoptera: Formicidae). Abhandlungen und Berichte des Naturkundemuseums Görlitz, 66 (5): $1-67$.

SEIFERT B. 2007. Die Ameisen Mittel- und Nordeuropas. Lutra Verlags- und Betriebsgesellschaft, Görlitz.

SEIFERT B. 2012a. A review of the West Palaearctic species of the ant genus Bothriomyrmex EMERY, 1869 (Hymenoptera: Formicidae). Myrmecological News, 17: 91-104.

SEIFERT B. 2012b. Clarifying naming and identification of the outdoor species of the ant genus Tapinoma FöRSTER, 1850 (Hymenoptera: Formicidae) in Europe north of the Mediterranean region with description of a new species. Myrmecological News, 16: 139-147.

SEIFERT B. 2013. Hypoponera ergatandria (FOREL, 1893) - a cosmopolitan tramp species different from H. punctatissima (RogeR, 1859) (Hymenoptera: Formicidae). Soil Organisms, 85 (3): 189201.

SeIfert B., OKITA I., Heinze J. 2017. A taxonomic revision of the Cardiocondyla nuda group (Hymenoptera: Formicidae). Zootaxa, 4290 (2): 324-356.

SHATTUCK S.O. 1994. Taxonomic catalog of the ant subfamilies Aneuretinae and Dolichoderinae (Hymenoptera: Formicidae). University of California Publications in Entomology, 112: 1-241.

Steiner F.M., Csősz S., Markó B., Gamisch A., Rinnhofer L., Fortelbauer C., Hammerle S., Staufer C., Arthofer W., Schlick-Steiner B.C. 2018. Turning one into five: integrative taxonomy uncovers complex evolution of cryptic species in the harvester ant Messor "structor". Molecular Phylogenetics and Evolution, 127: 387-404.

Süss L. 1979. Formiche infestanti l'industria alimentare: esperienze di difesa antiparassitaria. [in:] G. Domenichini (ed.). Atti $2^{\circ}$ Simposio "La difesa antiparassitaria nelle industrie alimentari e la protezione degli alimenti”, Piacenza 28-30 settembre 1977. Tip.Le.Co., Piacenza, 359-366.

TAHeRI A., Reyes-LóPez J. 2018. Exotic Ants (Hymenoptera: Formicidae) in Morocco: Checklist, Comments and New Faunistic Data. Transactions of the American Entomological Society, 144 (1): 99-107.

Trontti K., Aron S., SundStröm L. 2006. The genetic population structure of the ant Plagiolepis $x e n e-$ implications for genetic vulnerability of obligate social parasites. Conservation Genetics, 7 (2): $241-250$ 
VAnkerkhoven F., Crèvecoeur L., Jacobs M., Muls D., Dekoninck W. 2018. Is Lasius bicornis (FöRSTER, 1850) a very rare ant species? (Hymenoptera: Formicidae). Bulletin de la Société royale belge d'Entomologie/Bulletin van de Koninklijke Belgische Vereniging voor Entomologie, 154: $37-43$.

Vigna Taglianti A., Audisio P.A., Belfiore C., Biondi M., Bologna M., Carpaneto G.M., De Biase A., De Felici S., Piattella E., Rachelli T., Zapparoli M.,Zoia S. 1993. Riflessioni di gruppo sui corotipi fondamentali della fauna W-paleartica ed in particolare italiana. Biogeographia - The Journal of Integrative Biogeography, 15: 129-149.

Wagner H.C., Arthofer W., Seifert B., Muster C., Steiner F., SCHLick-Steiner B.C. 2017. Light at the end of the tunnel: Integrative taxonomy delimits cryptic species in the Tetramorium caespitum complex (Hymenoptera: Formicidae). Myrmecological News, 25: 95-129.

WARD P. S. 2005. A synoptic review of the ants of California. Zootaxa, 936 (1): 1-68.

WARD P.S., Brady S.G., Fisher B.L., SchUltz T.R. 2015. The evolution of myrmicine ants: phylogeny and biogeography of a hyperdiverse ant clade (Hymenoptera: Formicidae). Systematic Entomology, 40 (1): 61-81.

WetTERER J.K. 2008. Worldwide spread of the longhorn crazy ant, Paratrechina longicornis (Hymenoptera: Formicidae). Myrmecological News, 11: 137-149.

WeTtERER J.K. 2009. Worldwide Spread of the Penny Ant, Tetramorium bicarinatum (Hymenoptera: Formicidae). Sociobiology, 54 (3): 1-20.

WETTERER J.K. 2010a. Worldwide spread of the wooly ant, Tetramorium lanuginosum (Hymenoptera: Formicidae). Myrmecological News, 13: 81-88.

WETTERER J.K. 2010b. Worldwide spread of the pharaoh ant, Monomorium pharaonis (Hymenoptera: Formicidae). Myrmecological News, 13: 115-129.

Wetteren J.K. 2011a. Worldwide Spread of Pheidole teneriffana (Hymenoptera: Formicidae). Florida Entomologist, 94 (4): 843-847.

WETTERER J.K. 2011b. Worldwide spread of the membraniferous dacetine ant, Strumigenys membranifera (Hymenoptera: Formicidae). Myrmecological News, 14: 129-135.

WETTERER J.K. 2012. Worldwide spread of the moorish sneaking ant, Cardiocondyla mauritanica (Hymenoptera: Formicidae). Sociobiology, 59 (3): 985-997.

WiLSON E.O. 1955. A monographic revision of the ant genus Lasius. Bulletin of the Museum of Comparative Zoology at Harvard College, 113 (1): 1-201.

Received: 2 August 2018

Accepted: 15 August 2018 